\title{
Peranan Pajak Daerah Dan Retribusi Daerah Terhadap Pendapatan Asli Daerah (PAD) di Kabupaten Lombok Barat
}

\author{
Muhamad Sayuti ${ }^{1}$ \\ ${ }^{1}$ Prodi Ekonomi Pembangunan FE Universitas Islam Al-Azhar \\ email: mrsay.mm@gmail.com
}

Received: 10 November, 2020; Accepted: 24 November 2020; Published: 15 Desember, 2020

\begin{abstract}
Abstrak
Penelitian ini bertujuan untuk mengetahui peranan pajak daerah dan retribusi daerah terhadap Pendapatan Asli Daerah (PAD) di Kabupaten Lombok Barat.Jenis penelitian adalah deskriptif dengan pendekatan kualitatif.Unit observasinya adalah pajak dan retribusi daerah Kabupaten Lombok Barat. Analisis dan Penafsiran data dengan cara reduksi data, verifikasi data, sajian data, dan penarikan kesimpulan.Hasil penelitian menunjukkan bahwa secara umum efektivitas Kabupaten Lombok Barat dalam melakukan pemungutan pajak dan retribusi daerah untuk meningkatkan pendapatan asli daerah (PAD) selama lima tahun terakhir cukup efektif dimana pada tahun 2015-2019 pajak daerah tertinggi terjadi pada tahun 2016 dengan persentase $88,89 \%$, sedangkan untuk retribusi daerah tertinggi terjadi pada tahun 2015 dengan persentase 100,43\%. Pajak Daerah dan Retribusi Daerah di Kabupaten Lombok Barat begitu sangat penting karena digunakan untuk membangun sarana dan prasarana untuk kepentingan masyarakat, misalnya pembangunan rumah sakit, lain-lain bentuk layanan masyarakat, selain itu pengembangan fisik/ lokalitas, pengembangan dunia usaha, kesempatan lapangan kerja dan pengembangan ekonomi masyarakat.
\end{abstract}

Kata kunci: pajak daerah; retribusi daerah; Pendapatan Asli Daerah (PAD).

\begin{abstract}
This study aims to determine the role of local taxes and levies on local revenue (PAD) in West Lombok Regency. This type of research is descriptive with a caulitative approach. The unit of observation is the regional taxes and levies of West Lombok Regency. Analysis and interpretation of data by means of data reduction, data verification, data presentation, and drawing conclusions. The results show that in general the effectiveness of West Lombok Regency in collecting local taxes and levies to increase local revenue (PAD) for the last five years is quite effective where in 2015-2019 the highest regional taxes occurred in 2016 with a percentage of $88.89 \%$, while the highest regional retribution occurred in 2015 with a percentage of $100.43 \%$. Local taxes and levies in West Lombok Regency are very important because they are used to build facilities and infrastructure for the benefit of the community, for example the construction of hospitals, other forms of community service, besides physical development / locality, business development, employment opportunities and community economic development.
\end{abstract}

Keywords: local taxes, local retribution, locally-generated revenue. 
Sayuti, Peranan Pajak Daerah Dan Retribusi Daerah Terhadap Pendapatan Asli Daerah (PAD) di Kabupaten Lombok Barat.

\section{PENDAHULUAN}

Indonesia adalah negara berkembang dalam pelaksanaan pembangunan merupakan suatu upaya meningkatkan segenap sumber daya yang dilakukan secara berencana dan berkelanjutan dengan pinsip daya guna yang merata dan berkeadilan, dalam hal tersebut dapat dikatakan bahwa pembangunan beriorentasi pada pembangunan masyarakat, dimana pendidikan menempati posisi yang utama dengan tujuan untuk membuka wawasan dan kesadaran warga akan arah dan citacita yang lebih baik(Effendi 2002).

Pembangunan suatu daerah harus mencakup tiga inti nilai, yaitu 1) Ketahanan(sustenance)merupakankemampuanuntukmemenuhikebutuhanpokok(sa ndang, pangan, papan, kesehatan dan proteksi); 2) Harga diri (selfesteem) merupakan Pembangunan haruslah memanusiakan.Dalam arti luas pembangunan suatu daerah haruslah meningkatkan kebanggaan sebagai manusia yang berada di daerah itu; 3) Kebebasan (Freedom forservitude)merupakan kebebasan bagi individu suatu Negara untuk berpikir, berkembang, berperilaku, dan berusaha untuk berpartisipasi dalam pembangunan(Todaro 2000)

Indonesia pun merupakan Negara kesatuan yang berbentuk republik dimana di dalamnya dikenal adanya daerah-daerah otonom sebagai konsekuensi dianutnya asas desentralisasi sesuai dengan ketentuan UU No.12 tahun 2008, Maka Ada 2 (dua) tingkatan daerah otonom (yaitu daerah yang berhak mengurus rumah tangganya sendiri), yang dibagi menjadi daerah tingkat I (Propinsi) dan daerah tingkat II (Kabupaten dan Kota Madya).Sejalan dengan UU No.12 tahun 2008 tentang pemerintahan daerah dan UU No.33 tahun 2004 tentang perimbangan keuangan antara pemerintah pusat dan pemerintah daerah, serta UU No.28 tahun 2009 tentang pajak daerah dan retribusi daerah.Berdasarkan Undang-Undang No. 33 Tahun 2004 Pendapatan Asli Daerah merupakan pendapatan yang diperoleh oleh daerah yang dipungut berdasarkan peraturan daerah. Adapun sumber-sumber pendapatan daerah antara lain: (a) Pendapatan Asli Daerah (PAD) yang terdiri dari Hasil pajak daerah, Hasil retribusi daerah, Hasil Pengelolaan Kekayaan Daerah Yang Dipisahkan, Lain-lain hasil Pendapatan Asli Daerah Yang Sah. (b) Pendapatan berasal dari pemberian pemerintah, yang terdiri dari Sumbangan dari 
Sayuti, Peranan Pajak Daerah Dan Retribusi Daerah Terhadap Pendapatan Asli Daerah (PAD) di Kabupaten Lombok Barat.

pemerintah, Sumbangan-sumbangan lain, yang diatur dengan peraturan perundang undangan dan lain-lain pendapatan yang sah.

Undang-Undang Nomor 32 Tahun 2004 menjelaskan definisi Otonomi Daerah yaitu hak, wewenang dan kewajiban daerah otonom untuk mengatur dan mengurus sendiri urusan pemerintah dan kepentingan masyarakat setempat sesuai dengan peraturan perundng- undangan. Undang-Undang No. 32 Tahun 2004 memberikan kewenangan kepada pemerintah dan memungkinkan daerah yang bersangkutan mengatur dan mengurus kepentingan masyarakat setempat, kewenangan otonomi yang luas mewajibkan pemerintah daerah untuk meningkatkan pelayanan dan kesejahteraan masyarakat secara demokratis, adil, merata serta berkesinambungan (Halim 2007).

Menurut UU Nomor 34 Tahun 2004 tentang Pajak Daerah dan Retribusi Daerah, definisi pajak daerah adalah iuran wajib yang dilakukan oleh orang pribadi atau badan keapada daerah tanpa imbalan langsung yang seimbang dan yang dapat dipaksakan berdasarkan peraturan perundang-undangan yang berlaku, yang digunakan untuk membiayai penyelenggaran pemerintah daerah dan pembangunan daerah. Retribusi Daerah adalah pungutan daerah sebagai pembayaran atas jasa atau pemberian izin tertentu ynag khusus disediakan atau diberikan oleh pemerintah daerah untuk kepentingan orang pribadi atau badan.Dalam perekonomian ada beberapa indikator yang digunakan untuk menentukan keberhasilan dalam pelaksanaan pembangunan daerah, salah satunya adalah Pendapatan Asli Daerah (PAD).Berikut disajikan grafik target dan realisasi Pendapatan Asli Daerah Kabupaten Lombok Barat Lima Tahun terakhir sebagai berikut:

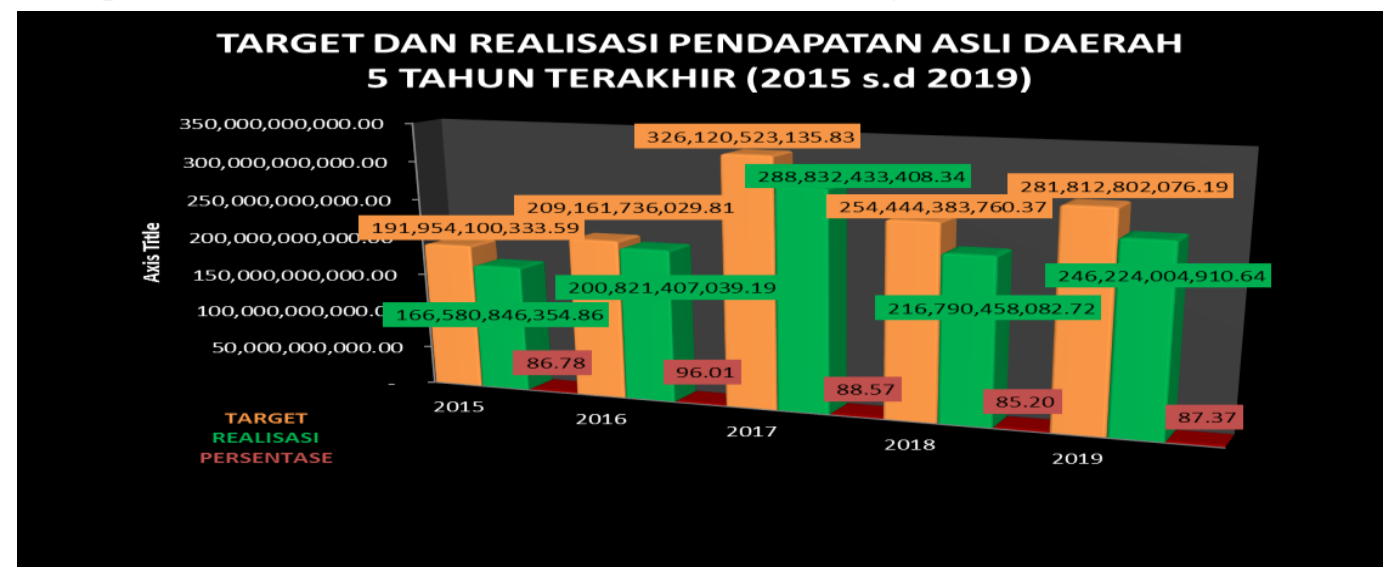


Sayuti, Peranan Pajak Daerah Dan Retribusi Daerah Terhadap Pendapatan Asli Daerah (PAD) di Kabupaten Lombok Barat.

Sumber: BPS Lombok Barat 2020

Gambar 1. Target dan Realisasi Pendapatan Asli Daerah, Kabupaten Lombok Barat

Berdasarkan informasi di atas terlihat bahwa Target dan Realisasi PAD Kabupaten Lombok Barat tertinggi dalam kurun waktu lima tahun terjadi pada tahun 2017 yaitu dimana target PAD sebesar Rp. 326.120.523.135,83 dan realisasi sebesar Rp. 288.832.433.408,34 dengan persentase sebesar 88,57\%, namun untuk pencapaian persentase progres tertinggi terjadi pada tahun 2016 yaitu sebesar 96,01 $\%$ dengan asumsi pencapaian realisasi hampir memenuhi target yang telah ditetapkan sebelumnya. Berikut disajikan pendapatan daerah yang sah yang terjadi selama lima tahun terakhir terlihat dalam grafik di bawah ini:

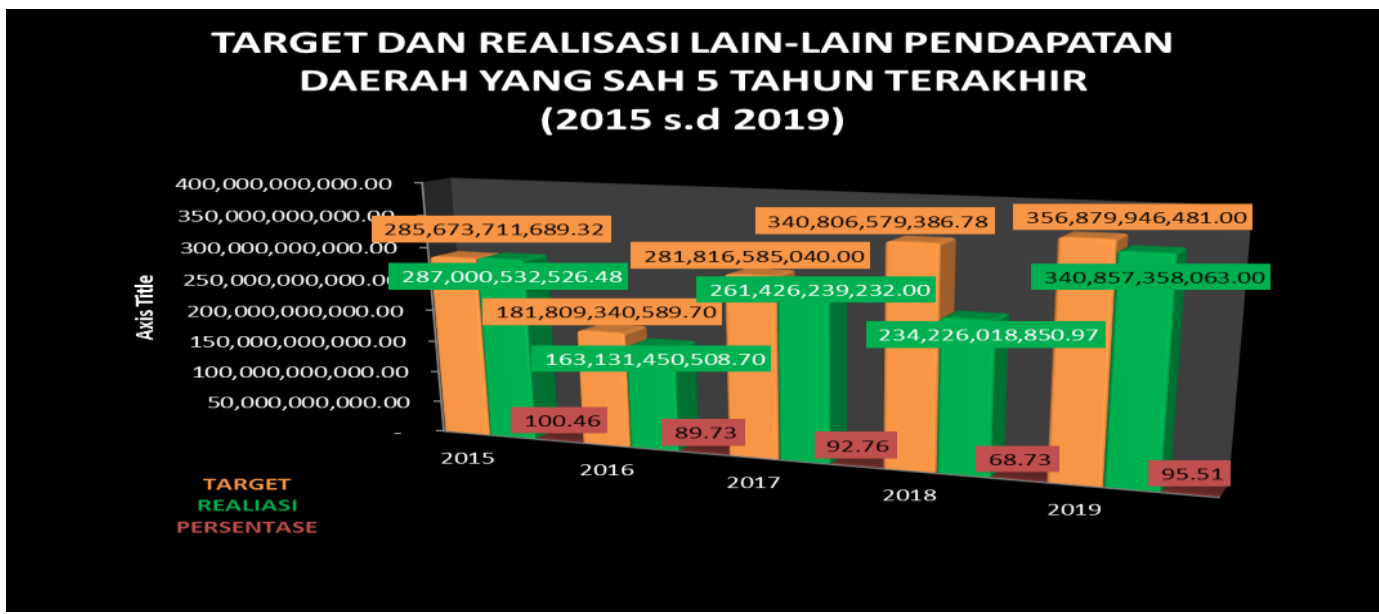

Sumber: BPS Kabupaten Lombok Barat

Gambar 2. Target dan realisasi lain-lain pendapatan daerah yang sah Kabupaten Lombok Barat

Berdasarkan grafik di atas terlihat bahwa target dan relaisasi lain-lain pendapatan daerah yang sah pada tahun 2015 memiliki persentase 100,46 yang bermakna pada tahun itu lain-lain pendapatan daerah yang sah melampaui dari target yang telah ditetapkan yaitu sebesar Rp. 285.673.711.689,32 sedangkan realisasinya sebesar Rp. 287.000.532.526,48. Sedangkan secara berturut persentse progress tahun 2019 memiliki capaian progress sebesar 95,51\% yang bermakna realisasi telah mendekati target yang ditetapkan pada tahun tersebut, dan yang memiliki persentase terendah yaitu pada tahun 2018 yang hanya mencapai 68,73 persen dari target yang telah ditetapkan.Penelitian ini menggunakan objek 
pemerintah daerah kabupaten dengan pertimbangan pemerintah daerah kabupaten merupakan unit pemerintahan yang dapat mengaplikasikan kebijakan anggaran untuk kepentingan rakyat di wilayah masing-masing secara langsung. Sehubungan dengan hal tersebut penulis ingin melakukan penelitian yang terfokus pada Peranan Pajak Daerah dan Retribusi Daerah terhadap pendapatan Asli Daeah Kabupaten Lombok Barat.

\section{METODE}

Jenis penelitian dalam penelitian ini adalah deskriptif dengan pendekatan kualitatif. Penelitian kualitatif pada hakikatnya adalah mengamati orang dalam lingkungan hidupnya, berinteraksi dengan mereka serta berusaha memahami bahasa dan tafsiran mereka tentang dunia sekitarnya (Nasution 1988). Penelitian akan dilakukan di Pemerintah Kabupaten Lombok Barat, dengan situs di Kantor Dinas Pendapatan, Badan Pengelola Keuangan dan Aset Daerah Kabupaten Lombok Barat. Teknik pengumpulan data yang digunakan Wawancara Mendalam (indeph Interview), Observasi (pengamatan), Dokumentasi. Pengecekan keabsahan data menggunakan Transfertabilitas, Kredibilitas, Dependabilitas, Konfirmabilitas. Analisis data mengunakan reduksi data, sajian data, dan penarikan kesimpulan (Moleong 2002).

\section{HASIL DAN PEMBAHASAN}

\section{Target dan Realisasi Pendapatan Asli Daerah Kabupaten Lombok Barat}

Kemampuan Pemerintah Daerah Provinsi dalam merealisasikan pajak dan retribusi daerah yang direncanakan dibandingkan dengan target yang ditetapkan berdasarkan potensi rill daerah dapat dilihat dalam tabel berikut ini:

Tabel:1

Perkembangan Pendapatan Asli Daerah Kabupaten Lombok Barat Tahun 2015-2019

\begin{tabular}{clccr}
\hline \multirow{2}{*}{ Tahun } & \multicolumn{1}{c}{ Uraian } & $\begin{array}{c}\text { Target } \\
(\mathrm{Rp})\end{array}$ & $\begin{array}{c}\text { Realisasi } \\
(\mathrm{Rp})\end{array}$ & $\%$ \\
\hline \hline \multirow{2}{*}{2015} & Pendapatan Asli & $181,642,784,017.59$ & $158,325,119,854.86$ & 87.16 \\
& Daerah & $89,241,721,256.59$ & $72,495,325,342.00$ & 81.23 \\
& Pajak Daerah & \multicolumn{2}{c}{ JPEK, Vol. 4, No. 2 Desember 2020. } & ・ 200
\end{tabular}




\begin{tabular}{llccc} 
& Retribusi Daerah & $11,892,589,502.00$ & $11,940,249,809.86$ & 100.4 \\
\hline \multirow{2}{*}{2016} & Pendapatan Asli & & & \\
& Daerah & $207,593,613,529.81$ & $199,753,284,539.19$ & 96.22 \\
& Pajak Daerah & $99,165,893,382.25$ & $88,147,896,583.63$ & 88.89 \\
& Retribusi Daerah & $13,325,468,452.20$ & $12,717,293,915.22$ & 95.44 \\
\hline \multirow{2}{*}{2017} & Pendapatan Asli & & & \\
& Daerah & $324,560,523,135.83$ & $287,963,869,408.34$ & 88.72 \\
& Pajak Daerah & $122,224,020,355.00$ & $102,830,694,745.87$ & 84.13 \\
& Retribusi Daerah & $16,215,908,782.00$ & $14,670,606,324.97$ & 90.47 \\
\hline \multirow{2}{*}{2018} & Pendapatan Asli & & & \\
& Daerah & $250,792,752,508.37$ & $216,949,707,052.80$ & 86.51 \\
& Pajak Daerah & $122,224,020,355.00$ & $102,830,694,745.87$ & 84.13 \\
& Retribusi Daerah & $16,215,908,782.00$ & $14,670,606,324.97$ & 90.47 \\
\hline \multirow{2}{*}{2019} & Pendapatan Asli & & & \\
& Daerah & $281,829,802,076.19$ & $247,090,175,185.16$ & 87.67 \\
& Pajak Daerah & $125,295,333,556.27$ & $104,892,172,182.92$ & 83.72 \\
& Retribusi Daerah & $19,455,172,100.00$ & $15,335,416,416.96$ & 78.82 \\
\hline
\end{tabular}

Sumber: Dinas Pendapatan dan BPKAD Kabupaten Lombok Barat

Dari tabel di atas diketahui bahwa rasio efektivitas Kabupaten Lombok Barat dalam melakukan pemungutan Pajak Daerah dan retribusi daerah Pada tahun 2015-2019 berfluktuasi. Namun secara garis besar realisasi yang dicapai belum memenuhi target yang telah ditetapkan oleh pemerintah daerah.

\section{Target dan Realisasi Pajak Daerah Kabupaten Lombok Barat}

Dari tabel 1 di atas diketahui Pemerintah DaerahKabupaten Lombok Barat dalam melakukan pemungutan pajak daerah mengalami fluktuasi pada lima tahun terakhir yaitu $81,23 \%$ tahun 2015, meningkat menjadi 88,89\% pada tahun 2016 turun menjadi $84,13 \%$ pada tahun 2017 , turun menjadi $73,58 \%$ pada tahun 2018 dan meningkat menjadi 83,27\% pada tahun 2019 . Hal ini menggambarkan bahwa Pemerintah Daerah Kabupaten Lombok Barat belum efektif dalam pemungutan pajak daerah, hal ini disebabkan karena realisasi pajak lebih kecil dibandingkan target yang telah ditetapkan pemerintah daerah Kabupaten Lombok Barat.

Berdasarkan sepuluh jenis pajak yang dipungut di Kabupaten Lombok Barat terdapat beberapa pajak unggulan sebagai pembentuk efektivitas pajaknya dimana realisasi lebih besar dibanding dengan target yang telah ditetapkan, pajak tersebut 
antara lain Pajak Reklame yang menempati posisi pertama dimana selama tahun 2015-2019 persentase yang bisa dicapai sebesar 142,58\%, 128,46\%, 111,73\%, $120,76 \%$. Pajak penerangan jalan menempati posisi kedua dalam pemebentuk efektivitas pajak dengan persentase berturut-turut sebesar 98\%, 103,43\%, 102,25\%, 101,90\%, 102,74\%. Kemudian disusul oleh pajak air tanah dan MINERBA yang berfluktuasi selama lima tahun terakhir.

\section{Target dan Realisasi Retrsibusi Daerah Kabupaten Lombok Barat}

Untuk mengetahui seberapa besar sumbangsih masing-masing komponen dalam membentuk Pajak Daerah, berikut disajikan data kontribusi pendukung dalam tabel di bawah ini:

Dari tabel 1 di atas diketahui Pemerintah DaerahKabupaten Lombok Barat dalam melakukan pemungutan retribusi daerah mengalami fluktuasi pada lima tahun terakhir yaitu 100,40\% tahun 2015, turun menjadi 95,44\% pada tahun 2016 turun menjadi $90,47 \%$ pada tahun 2017 , turun menjadi $80,54 \%$ pada tahun 2018 dan turun menjadi 78,82\% pada tahun 2019 . Hal ini menggambarkan bahwa Pemerintah Daerah Kabupaten Lombok Barat belum efektif dalam pemungutan retribusi daerah, hal ini disebabkan karena realisasi retribusi lebih kecil dibandingkan target yang telah ditetapkan pemerintah daerah Kabupaten Lombok Barat.

\section{Peranan Pajak Daerah dan Retribusi Daerah di Dalam Pendapatan Asli Daerah (PAD)}

Pada hakekatnya pembangunan dapat dilihat salah satunya dari definisi pembangunanyaitu bahwa pembangunan biasanya didefinisikan sebagai rangkaian usaha untuk mewujudkan pertumbuhan dan perubahan secara terencana ditempuh oleh suatu bangsa menuju modernitas dalam rangka pembinaan bangsa(Siagian 2008).Dari definisi tersebut di atas sedikitnya ada 7 (tujuh)ide pokok mengenai pembangunan yang merupakan suatu proses, artinya pembangunan ini merupakan rangkaian kegiatan yang berlangsung secara berkelanjutan dan terdiri dari tahaptahap disuatu pihak bersifat tanpa akhir.Kedua, pembangunan merupakan upaya yang secara sadar ditetapkan sebagai suatu untuk dilaksakan. Ketiga, pembangunan dilaksanakan secara terencana baik dalam arti jangka pendek,jangka menengah dan 
Sayuti, Peranan Pajak Daerah Dan Retribusi Daerah Terhadap Pendapatan Asli Daerah (PAD) di Kabupaten Lombok Barat.

jangka panjang.Keempat, rencana pembangunan mengandung makna pertumbuhan dan perkembangan. Kelima, pembangunan mengarah pada modernitas yakni cara hidup yang baru dan lebih baik dari sebelumnya. Cara berpikir rasional dan sistem budaya yang kuat tetap fleksibel.Keenam, modernitas yang ingin dicapai melalui berbagai kegiatan pembangunan.Tujuh, sarana ditujukan untuk mengukuhkan pondasi dan memantapkan keberadaan suatu bangsa menjadi negara yang sejajar dengan negara dan bangsa lain.

Retribusi daerah sebagaimana halnya pajakdaerahmerupakansalah satu Pendapatan Asli Daerah yang diharapkan menjadi salah satu sumber pembiayaan. Dalam UU. No. 34 Tahun 2000 tentang Pajak Daerah dan Retribusi Daerah menetapkan ketentuan-ketentuan pokok yang memberikan pedoman kebijaksanaan dan arahan bagi Daerah dalam pelaksanaan pemungutan Pajak Daerah dan Retribusi Daerah, juga menetapkan pengaturan yang cukup rinci untuk menjamin prosedur umum perpajakan dan Retribusi Daerah. Penyelenggaraan Pemerintah Daerah sebagai subsistem Pemerintah Negara dimaksudkan untuk meningkatkan dayaguna dan hasil guna penyelenggaraan Pemerintah dan pelayanan Masyarakat sebagai Daerah Otonomi.

\section{Peran danPosisi Retribusi DaerahDalamKerangka Otonomi Daerah}

Dalam otonomi, hubungan kewenangan antara PusatdanDaerah,antaralain bertalian dengan cara pembagian urusan penyelenggaraan pemerintahan atau cara menentukan urusan rumah tangga daerah. Cara tersebut akan mencerminkan suatu bentuk otonomi terbatas atau otonomi luas (Huda Ni'matul 2009).

Otonomi terbatas digolongkan kedalam beberapa kelompok, diantaranya: pertama, urusan-urusan rumah tangga daerah ditentukan secara kategoris dan pengembangannya diatur dengan cara-cara tertentu pula. Kedua, apabila sistem supervise dan pengawasan dilakukan sedemikian rupa, sehingga daerah otonom kehilangan kemandirian untuk menentukan secara bebas cara-cara mengaturdan mengurus rumah tangga daerahnya. Ketiga, system hubungank euanganantara pusat dan daerahyang menimbulkan hal-hal seperti keterbatasan kemampuan keuangan asli daerah yang akan membatasi ruang gerak otonomi daerah (Bagir 1994). 
Salah satu kriteria penting untuk mengetahui secara nyata kemampuan Daerahdalam mengatur dan mengurus rumah tangganya adalah kemampuan self supporting dalam bidang keuangan. Sehubungan denganpentingnya posisi keuangan ini, Pemerintah Daerah tidakakan dapat melaksanakan fungsinya dengan efektif dan efisien tanpa biaya yang cukup untuk memberikan pelayanan dan pembangunan dan keuangan inilah yang merupakan salah satu dasar criteria untuk mengetahui secara nyata kemampuan daerah dalam mengurus rumah tangganya sendiri”(Pamudji 1980).

Untuk dapat memiliki pendanaan yang memadai, daerah membutuhkan sumber perndanaan yang cukup. Daerah dalam hal ini dapat memperolehnya melalui beberapa cara yakni: pertama, mengumpulkan dana dari pajak daerahyang telah disetujui oleh Pemerintah Pusat. Kedua, melakukan pinjaman dari pihak ketiga, pasar uang atau bank atau melalui Pemerintah Pusat. Ketiga, mengambil bagian dalam pendapatan pajak pusat yang dipungut daerah. Keempat, menambahkan tariff pajak pusat tertentu, misalnya pajak kekayaan atau pajak pendapatan. Kelima, bantuan atau subsidi dari pemerintah pusat.

Berdasarkan analisis pajak dan retribusi daerah, ternyata rasio kenaikan penerimaan daerah dari retribusi daerah sejak otonomi daerah lebih tinggi dibanding rasio kenaikan penerimaan daerah dari pajak daerah, terutama di kabupaten kota. Oleh Tjip ditegaskan bahwa hal tersebut sebagai bukti bahwa masyarakat lebih merasa rela membayar retribusi daerah daripada pajak daerah yang manfaat/kontraprestasinya tidak dirasakan langsung. Ada beberapa permasalahan yang terjadi di daerah berkaitan dengan penggalian dan peningkatan PAD, beberapa diantaranya (Tjip 2005): 1) Relatif rendahnya basispajak dan retribusi daerah. Berdasarkan UU. No. 34 Tahun 2000 daerah Kabupaten/Kota dimungkinkan untuk menetapkan jenis pajak dan retribusi baru. Namun, melihat criteria pengadaan pajak baru sangat ketat, khususnya criteria pajak daerah tidak boleh tumpang tindih dengan Pajak Pusat dan Pajak Propinsi, diperkirakan daerah memiliki basis pungutan yang relative rendah dan terbatas, serta sifatnya bervariasi antar daerah. Rendahnya basis pajak ini bagi sementara daerah berarti memperkecil kemampuan manuver keuangan daerah dalam menghadapi krisis ekonomi; 2) 
Perannya yang tergolong kecil dalam total penerimaan daerah Sebagian besar penerimaan daerah masih berasal dari bantuan Pusat. Dari segi upaya pemungutan pajak, banyaknya bantuan dan subsidi ini mengurangi "usaha" daerah dalam pemungutan PAD-nya, dan lebih mengandalkan kemampuan "negosiasi" daerah terhadap Pusat untuk memperoleh tambahan bantuan; 3) Kemampuan administrasi pemungutan di daerahyangmasih rendahserta kemampuan perencanaan dan pengawasan keuangan yang lemah.

Hal ini mengakibatkan bahwa pemungutan pajak cenderung dibebani oleh biaya pungut yang besar. PAD masih tergolong memiliki tingkat buoyancy yang rendah. Salah satu sebabnya adalah diterapkan sistem"target" dalampungutan daerah. Sebagai akibatnya beberapa daerah lebih condong memenuhitargettersebut, walaupun dari sisi pertumbuhan ekonomi sebenarnya pemasukkan pajak dan retribusi daerah dapat melampaui target yang ditetapkan (Halim 2007).

\section{KESIMPULAN}

Berdasarkan uraian tersebut di atas, maka dapat diketahui kesimpulan sebagaiPemerintah DaerahKabupaten Lombok Barat dalam melakukan pemungutan pajak daerah mengalami fluktuasi pada lima tahun terakhir yaitu $81,23 \%$ tahun 2015, meningkat menjadi 88,89\% pada tahun 2016 turun menjadi $84,13 \%$ pada tahun 2017, turun menjadi 73,58\% pada tahun 2018 dan meningkat menjadi $83,27 \%$ pada tahun 2019 . Sedangkan untuk retribusi daerah yaitu $100,40 \%$ tahun 2015, turun menjadi 95,44\% pada tahun 2016 turun menjadi 90,47\% pada tahun 2017, turun menjadi 80,54\% pada tahun 2018 dan turun menjadi 78,82\% pada tahun 2019. Hal ini menggambarkan bahwa Pemerintah Daerah Kabupaten Lombok Barat belum efektif dalam pemungutan pajak dan retribusi daerah dikarenakan realisasi pajak lebih kecil dibandingkan target yang telah ditetapkan sebelmnya. 2) Secara umum Kabupaten Lombok Barat dalam melakukan pemungutan pajak dan retribusi daerah untuk meningkatkan pendapatan asli daerah selama lima tahun terakhir cukup efektif dimana pada tahun 2015-2019 pajak daerah tertinggi terjadi pada tahun 2016 dengan persentase 88,89\%, sedangkan untuk retribusi daerah tertinggi terjadi pada tahun 2015 dengan persentase 100,43\%. Pajak Daerah dan 
Sayuti, Peranan Pajak Daerah Dan Retribusi Daerah Terhadap Pendapatan Asli Daerah (PAD) di Kabupaten Lombok Barat.

Retribusi Daerah di Kabupaten Lombok Barat begitu sangat penting karena berperan untuk membangun sarana dan prasarana untuk penunjang kebutuhan masyarakat, misalnya pembangunan rumah sakit, lain-lain bentuk layanan masyarakat, selain itu pengembangan fisik/ lokalitas, pengembangan dunia usaha, kesempatan lapangan kerja dan pengembangan ekonomi masyarakat.

\section{DAFTAR RUJUKAN}

Bagir, Manan. 1994. "Hubungan Antara Pusat Dan Daerah Menurut UUD 1945." Sinar Harapan.

Effendi, Bachtiar. 2002. Pembangunan Daerah Otonomi Berkeadilan. Yogyakarta: Salemba Empat.

Halim, Abdul. 2007. Akuntansi Sektor Publik: Akuntansi Keuangan Daerah. Jakarta: Salemba Empat.

Huda Ni'matul. 2009. Otonomi Daerah (Filosofi, Sejarah Perkembangan Dan Problematika). Yogyakarta: Pustaka Pelajar.

Moleong, Lexy J. 2002. Metodologi Penelitian Kualitatif. Bandung: PT. Remaja Rosdakarya.

Nasution, S. 1988. Metode Penelitian Naturalistik Kualitatif. Bandung: Tarsiti.

Pamudji, S. 1980. Pembinaan Perkotaan Di Indonesia. Jakarta: Ichtiar.

Siagian, Sondang P. 2008. Adminitrasi Pembangunan. Jakarta: PT. Bumi Aksara.

Tjip, Ismail. 2005. Pengaturan Pajak Daerah Di Indonesia. Jakarta: PT. Yellow Media Tama.

Todaro, Michael P. 2000. Pembangunan Ekonomi Di Dunia Ketiga Edisi Ketujuh. Edisi Keen. Jakarta: Erlangga. 